\begin{tabular}{ll|l|lll}
\hline $\begin{array}{l}\text { Psychopathology } \\
\text { 47(3) 141-206(2014) }\end{array}$ & $\mathbf{4 7}$ & $\mathbf{3}$ & $\mathbf{1 4}$ & $\begin{array}{l}\text { print } \\
\text { ISSN 0254-4962 }\end{array}$ & $\begin{array}{l}\text { online } \\
\text { e-ISSN 1423-033X }\end{array}$ \\
\hline
\end{tabular}

International Journal of

Descriptive and

Experimental Psychopathology,

Phenomenology and

Psychiatric Diagnosis

S. Karger

Medical and Scientific Publishers

Basel $\cdot$ Freiburg · Paris ·

London - New York · Chennai ·

New Delhi · Bangkok · Beijing .

Shanghai · Tokyo · Kuala Lumpur -

Singapore · Sydney
KARGER

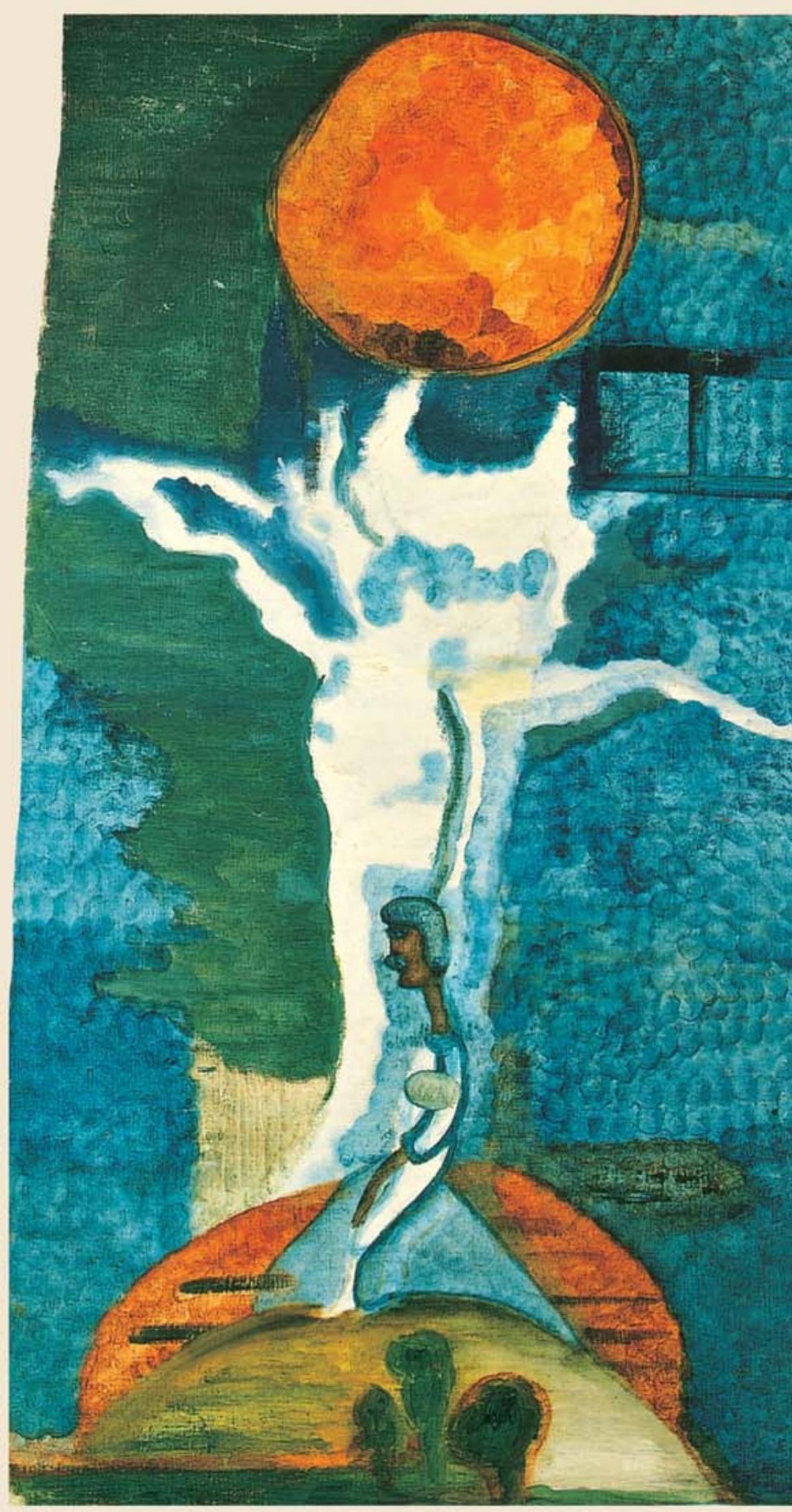




\section{New scientific approaches and insights into children's emotional development}

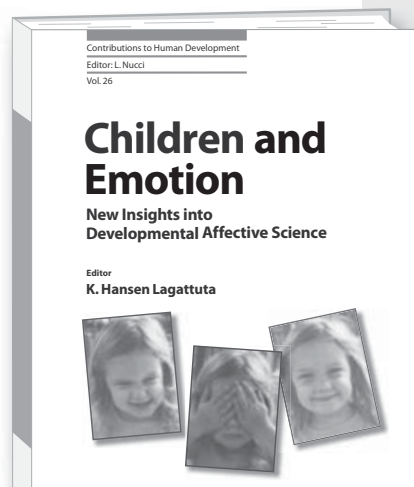

KARGER

\section{Children and Emotion}

New Insights into

Developmental Affective Science

\author{
Editor \\ Kristin Hansen Lagattuta
}

\section{Children and Emotion}

New Insights into

Developmental Affective Science

Editor: Hansen Lagattuta, K. (Davis, Calif.)

$X+122$ p., 1 fig., 2014

CHF 44.- / EUR 37.- / USD 52.00 (soft cover)

CHF 53.- / EUR 44.- / USD 62.00 (online)

Online version for institutional purchase

Prices subject to change

EUR price for Germany, USD price for USA and

Latin America only

ISBN 978-3-318-02488-3 (soft cover)

e-ISBN 978-3-318-02489-0

Contributions to Human Development, Vol. 26 Series Editor: Nucci, L. (Berkeley, Calif.)

Listed in MEDLINE/PubMed

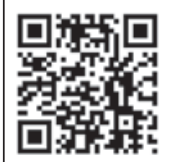

Dear Librarian

I have reviewed this publication and

would like to recommend it for our library.

Recommended by:

Department:

Date:

Signature:

Orders may be placed with any bookshop,
This publication brings together leading emotion researchers whose work has pioneered new questions, methods, and levels of analyses for investigating development and individual differences in how infants and children attend to, categorize, understand, talk about, and regulate emotions. Topics include infant attention and processing of emotions, developmental affective psychophysiology, emotions in maltreated children, attention biases and anxiety, emotional competence and social interactions, cultural differences in emotion socialization, gender and parent-child reminiscing about emotional events, family emotion conversations and socio-cognitive development, and causal reasoning about emotions. These contributions lay a foundation for new scientific discoveries in developmental affective science, and they inform evidence-based practices and interventions aimed at promoting children's emotional well-being. Given the centrality of emotions to children's development, this volume provides a valuable resource for developmental researchers and clinicians, as well as for parents, educators, and policy makers.

\section{Contents}

- Introduction: Integrated Approaches to Studying the Development of Emotion: Hansen Lagattuta, $\mathbf{K}$. - Emotion Processing in Infancy: Hoehl, S.

- Developmental Affective Psychophysiology: Using Physiology to Inform our Understanding of Emotional Development: Hastings, P.D.; Kahle, S.S.; Han, G.H.-P.

- Emotional Development in Maltreated Children: Cicchetti, D.; Ng, R.

- Temperament and Attention as Core Mechanisms in the Early Emergence of Anxiety: Pérez-Edgar, K.; Taber-Thomas, B.; Auday, E.; Morales, S.

- Emotional Competence and Social Relations: Lemerise, E.A.; Harper, B.D.

-Emotion Socialization in the Family with an Emphasis on Culture: Camras, L.A.; Shuster, M.M.; Fraumeni, B.R.

- Gender and Voice in Emotional Reminiscing: Fivush, $\mathbf{R}$.

- How Does Talk about Thoughts, Desires, and Feelings Foster Children's Socio-Cognitive Development? Mediators, Moderators, and Implications for Intervention: Hughes, C.; White, N.

- The Mysterious Emotional Life of Little Red

Riding Hood: Harris, P.L.; de Rosnay, M.; Ronfard, S. 


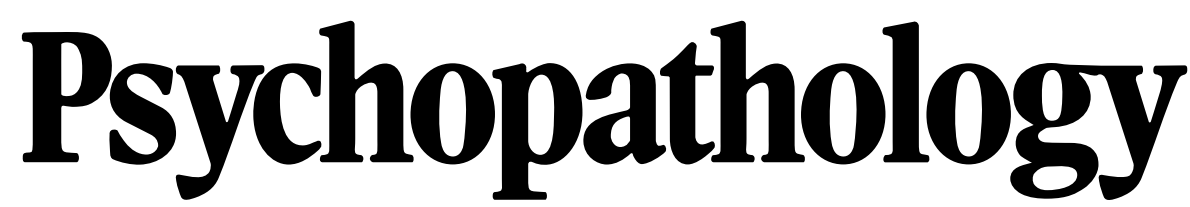

International Journal of Descriptive and Experimental Psychopathology, Phenomenology and Psychiatric Diagnosis

Founded 1897 as 'Monatsschrift für Psychiatrie und Neurologie', continued 1957-1967 as 'Psychiatria et Neurologia', continued $1968-1983$ as 'Psychiatria Clinica'

Founders: C. Wernicke and Th. Ziehen

Successors: K. Bonhoeffer (1912-1938), J. Klaesi (1939-1967), E. Grünthal (1953-1973),

N. Petrilowitsch (1968-1970), Th. Spoerri (1971-1973), P. Berner (1974-1999),

E. Gabriel (1974-2004), Ch. Mundt (2000-2011)

\section{Editors-in-Chief}

S.C. Herpertz, Heidelberg

T. Fuchs, Heidelberg

\section{Honorary Consultant Editor}

K.S. Kendler, Richmond, Va.

\section{Editorial Assistant}

S. Neidlein, Heidelberg

\section{Section Editors}

T. Fuchs, Heidelberg

V. Gallese, Parma

S.C. Herpertz, Heidelberg

P. McGorry, Melbourne, Vic.

\section{Editorial Board}

A. Arntz, Maastricht

D. Bhugra, London

A. Buchheim, Innsbruck

F. Caspar, Bern

A.M. Chanen, Parkville, Vic.

Y.-F. Chen, Beijing

A.S. David, London

N.M.J. Edelstyn, Keele

H. Fabisch, Graz

K. Fabisch, Graz

P. Falkai, München

H.J. Freyberger, Greifswald/ Stralsund

S.N. Ghaemi, Boston, Mass.

J.G. Gunderson, Belmont, Mass.

M. Härter, Hamburg

A. Heerlein, Santiago

P. Henningsen, München

H.P. Kapfhammer, Graz

J. Klosterkötter, Köln

M.F. Lenzenweger,

Binghamton, N.Y.

S. Löber, Heidelberg

W. Maier, Bonn

M. Maj, Naples

Ch. Mundt, Heidelberg

J. Parnas, Copenhagen
C. Reck, Heidelberg

F. Resch, Heidelberg

F. Schneider, Aachen

K. Schnell, Heidelberg

L. Siever, New York, N.Y.

K. Silk, Ann Arbor, Mich.

C. Sinigaglia, Milan

G. Stanghellini, Florence

E. Vieta, Barcelona

M. Weisbrod, Karlsbad

A.R. Yung, Parkville, Vic. 


\section{Psychopathology}

Psychopathology addresses scientists who work on descriptive psychopathology in clinical contexts, or with experimental methods in neuropsychology and experimental psychopathology, or on conceptual framing of psychopathological findings for understanding pathogenesis and for validation of diagnosis and classification. They may include an interdisciplinary approach to other medical and biological fields or to the humanities. Psychopathology does not only invite reports on medical research but also wants to address psychologists who refer to pathological phenomena or work within clinical settings. The central field of interest is the con vergence of clinical phenomena, experimental findings, and conceptualisation. This would also include describing pathogenetic mechanisms of disturbed neuropsychological functions which allows remodelling and evaluation of psychotherapeutic tools.

\section{Types of Papers}

Psychopathology accepts papers on the three following sections: Original Paper, Review, Short Report (up to 8 man uscript pages). Reviews may contain overviews, meta-analyses and conceptual papers based on a literature overview; Original Papers contain data generated by the authors; Shor Reports will also be restricted to relevant issues of scientific debate.

\section{Submission}

Only original papers written in English are considered and should be submitted using the online submission website at:

\section{www.karger.com/psp}

Should you experience any problems with your submission, please contact:

Shirin.Neidlein@med.uni-heidelberg.de
Editorial Office Psychopathology
Zentrum für Psychosoziale Medizin
Klinik für Allgemeine Psychiatrie
Universität Heidelberg
Voßstr. 4
D-69115 Heidelberg
Tel. +496221567308
Fax +496221565477

\section{Conditions}

All manuscripts are subject to editorial review. Manuscripts are received with the explicit understanding that they are not under simultaneous consideration by any other publication. Submission of an article for publication implies the transfer of the copyright from the author to the publisher upon acceptance. Accepted papers become the permanent property of Psychopathology and may not be reproduced by any means, in whole or in part, without the written consent of the publisher. It is the author's responsibility to obtain permission to reproduce illustrations, tables, etc. from other publications.

\section{Arrangement}

Title page: The first page of each paper should indicate the title, the authors' names, the institute where the work was conducted, and a short title for use as running head.

Full address: The exact postal address of the corresponding author complete with postal code must be given at the bottom of the title page. Please also supply phone and fax numbers, as well as e-mail address.

Key words: Please supply 3-10 key words in English that reflect the content of the paper.

Abstract: The abstract should not exceed 30 lines and should be structured as follows: Background, Sampling and Methods, Results, and Conclusions (including study limitations).
Methods: Sampling should be described in detail so that possible selection biases may be discussed. Methods should be reported in a manner enabling easy replication.

Results: The results should be described precisely and must be separated from the discussion.

Discussion: The discussion should move along the same lines as the results and should discuss the relevant literature with regard to consistencies and inconsistencies as well as elucidate on the theoretical and practical implications of the results. Further research perspectives may be addressed, e.g. concerning clarification of inconsistencies with the literature.

Footnotes: Avoid footnotes. When essential, they are numbered consecutively and typed at the foot of the appropriate page.

Tables and illustrations: Tables and illustrations (both numbered in Arabic numerals) should be prepared on separate sheets. Tables require a heading and figures a legend, also prepared on a separate sheet. For the reproduction of illustrations, only good drawings and original photographs can be accepted; negatives or photocopies cannot be used. Due to technical reasons, figures with a screen background should not be submitted. When possible, group several illustrations on one block for reproduction (max. size $180 \times 223 \mathrm{~mm}$ ) or provide crop marks. Electronically submitted $b / w$ half-tone and color illustrations must have a final resolution of $300 \mathrm{dpi}$ after scaling, line drawings one of 800-1,200 dpi.

\section{Color illustrations}

Online edition: Color illustrations are reproduced free of charge. In the print version, the illustrations are reproduced in black and white. Please avoid referring to the colors in the text and figure legends.

Print edition: Up to 6 color illustrations per page can be integrated within the text at CHF 800.- per page.

References: In the text, identify references by Arabic numerals [in square brackets]. Material submitted for publication but not yet accepted should be noted as [unpublished data] and not be included in the reference list. The list of references should include only those publications which are cited in the text. Do not alphabetize; number references in the order in which they are first mentioned in the text. The surnames of the authors followed by initials should be given. There should be no punctuation other than a comma to separate the authors. Preferably, please cite all authors. Abbreviate journal names according to the Index Medicus system. Also see International Committee of Medical Journal Editors: Uniform requirements for manuscripts submitted to biomedical journals (www.icmje.org).

\section{Examples}

(a) Papers published in periodicals: Sun J, Koto H, Chung KF: Interaction of ozone and allergen challenges on bronchial responsiveness and inflammation in sensitised guinea pigs. Int Arch Allergy Immunol 1997;112:191-195.

(b) Papers published only with DOI numbers:

Theoharides TC, Boucher W, Spear K: Serum interleukin-6 reflects disease severity and osteoporosis in mastocytosis patients. Int Arch Allergy Immunol DOI: 10.1159/000063858 (c) Monographs: Matthews DE, Farewell VT: Using and Understanding Medical Statistics, ed 3, revised. Basel, Karger, 1996.

(d) Edited books: Parren PWHI, Burton DR: Antibodies against HIV-1 from phage display libraries: Mapping of an immune response and progress towards antiviral immunotherapy; in Capra JD (ed): Antibody Engineering. Chem Immunol. Basel, Karger, 1997, vol 65, pp 18-56.

Reference Management Software: Use of EndNote is recommended for easy management and formatting of citations and reference lists.

\section{Digital Object Identifier (DOI)}

S. Karger Publishers supports DOIs as unique identifiers for articles. A DOI number will be printed on the title page of each article. DOIs can be useful in the future for identifying and citing articles published online without volume or issue information. More information can be found at www. doi.org.

\section{Supplementary Material}

Supplementary material is restricted to additional data that are not necessary for the scientific integrity and conclusion of the paper. Please note that all supplementary files will undergo editorial review and should be submitted together with the original manuscript. The Editors reserve the right to limit the scope and length of the supplementary material. Supplementary material must meet production quality standards for Web publication without the need for any modification or editing. In general, supplementary files should not exceed $10 \mathrm{Mb}$ in size. All figures and tables should have titles and legends and all files should be supplied separately and named clearly. Acceptable files and formats are: Word or PDF files, Excel spreadsheets (only if the data cannot be converted properly to a PDF file), and video files (.mov, .avi, .mpeg).

\section{Author's Choice ${ }^{\mathrm{TM}}$}

With this option the author can choose to make his article freely available online against a one-time fee of CHF 3000.This fee is independent of any standard charges for supplementary pages, color images etc. which may apply. More in formation can be found at www.karger.com/authors_choice.

\section{NIH-Funded Research}

The U.S. National Institutes of Health (NIH) mandates un der the NIH Public Access Policy that final, peer-reviewed manuscripts appear in its digital database within 12 months of the official publication date. As a service to authors, Karger submits the final version of your article on your behalf to PubMed Central (PMC) immediately upon publishing. It usually receives a PMCID within approximately a month and will appear in PMC after 12 months. For those selecting our premium Author's Choice ${ }^{\mathrm{TM}}$ service, the usual embargo will be overriden, accelerating the accessibility of your work More details on NIH's Public Access Policy are available at http://publicaccess.nih.gov/policy.htm

\section{Self-Archiving}

Karger permits authors to archive their pre-prints (i.e. prerefereeing) or post-prints (i.e. final draft post-refereeing) on their personal or institution's servers, provided the following conditions are met: Articles may not be used for commercial purposes, must be linked to the publisher's version, and must acknowledge the publisher's copyright. Authors selecting Karger's Author's Choice ${ }^{\mathrm{TM}}$ feature, however, are also permitted to archive the final, published version of their article, which includes copyediting and design improvements as well as citation links.

\section{Page Charges}

There is no page charge for papers of 5 or fewer printed pages (including tables, illustrations and references). Each additional complete or partial page is charged to the author at CHF 325.-. The allotted size of a paper is equal to approx. 14 manuscript pages (double-spaced, including tables, illustrations and references).

\section{Proofs}

Unless indicated otherwise, proofs are sent to the corresponding author and should be returned with the least possible delay. Alterations other than the correction of printer's errors are charged to the author.

\section{Reprints}

Order forms and a price list are sent with the proofs. Order submitted after the issue is printed are subject to considerably higher prices.

\section{KARGER}

E-Mail karger@karger.com www.karger.com
(C) 2014 S. Karger AG, Basel 


\section{Psychopathology}

ISSN Print Edition: 0254-4962

ISSN Online Edition: 1423-033X

Journal Homepage: www.karger.com/psp

Publication Data: Psychopathology is published 6 times a year. Volume 47 with 6 issues appears in 2014 .

Copyright: () 2014 S. Karger AG, Basel (Switzerland). All rights reserved. No part of this publication may be translated into other languages, reproduced or utilized in any form or by any means, electronic or mechanical, including photocopying, recording, microcopying, or by any information storage and retrieval system, without permission in writing from the publisher or, in the case of photocopying, direct payment of a specified fee to the Copyright Clearance Center.

Disclaimer: The statements, opinions and data contained in this publication are solely those of the individual authors and contributors and not of the publisher and the editor(s). The appearance of advertisements in the journal is not a warranty, endorsement, or approval of the products or services advertised or of their effectiveness, quality or safety. The publisher and the editor(s) disclaim responsibility for any injury to persons or property resulting from any ideas, methods, instructions or products referred to in the content or advertisements.
Subscription Rates: Subscriptions run for a full calendar year. Prices are given per year. Personal subscription:

Print or Online

CHF 230.-

EUR 189.-

USD 230.00

Print+Online combined CHF 278.-

EUR 228.-

USD 278.00

postage and handling (added to print and print+online)

CHF 44.40 Europe, CHF 64.80 Overseas

EUR 36.-

USD 58.80

Institutional subscription:

Print or Online

Print+Online combined

CHF 1854.-

EUR 1520.-

CHF 2039.-

postage and handling (added to print and print+online)

CHF 55.50.- Europe, CHF 81.- Overseas

EUR 45.-

USD 73.50

Discount subscription prices: Various related societies.
Back Volumes and Single Issues: Information on availability and prices of single print issues and print or electronic back volumes can be obtained from Customer Service atservice@karger.com.

Bibliographic Indices: This journal is regularly listed in bibliographic services, including Current Contents ${ }^{\circledR}$ and PubMed/MEDLINE.

Photocopying: This journal has been registered with the Copyright Clearance Center (CCC), as indicated by the code appearing on the first page of each article. For readers in the US, this code signals consent for copying of articles for personal or internal use, or for the personal or internal use of specific clients, provided that the stated fee is paid per copy directly to

Copyright Clearance Center Inc.

222 Rosewood Drive

Danvers, MA 01923 (USA)

A copy of the first page of the article must accompany payment. Consent does not extend to copying for general distribution, for promotion, for creating new works, or for resale. In these cases, specific written permission must be obtained from the copyright owner,

S. Karger AG, P.O. Box

CH-4009 Basel (Switzerland).

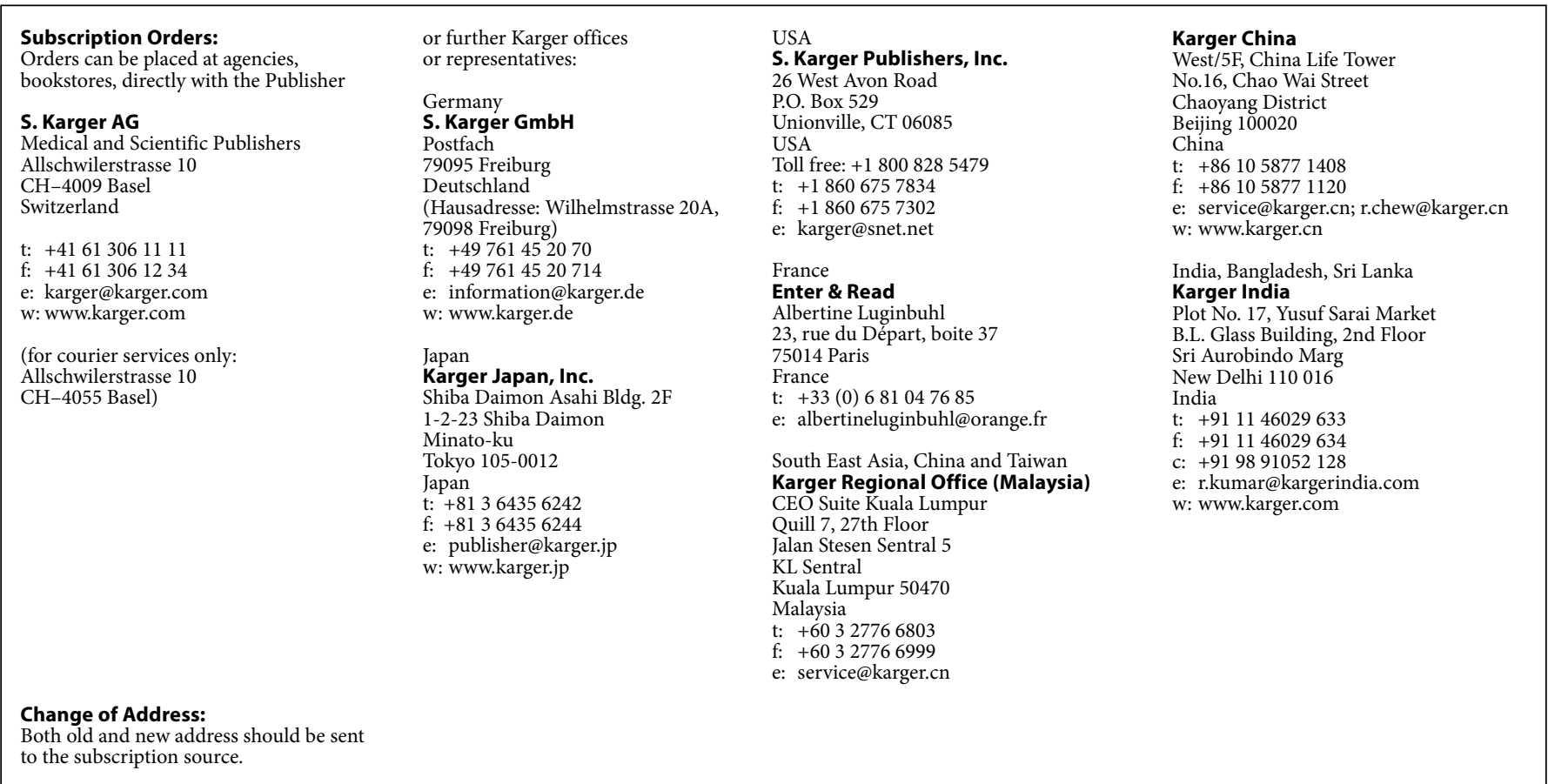

\section{KARGER}

E-Mail karger@karger.com www.karger.com (c) 2014 S. Karger AG, Basel

The Journal Home Page is available at: www.karger.com/psp 


\section{4}

psychiatrie-kongress.ch
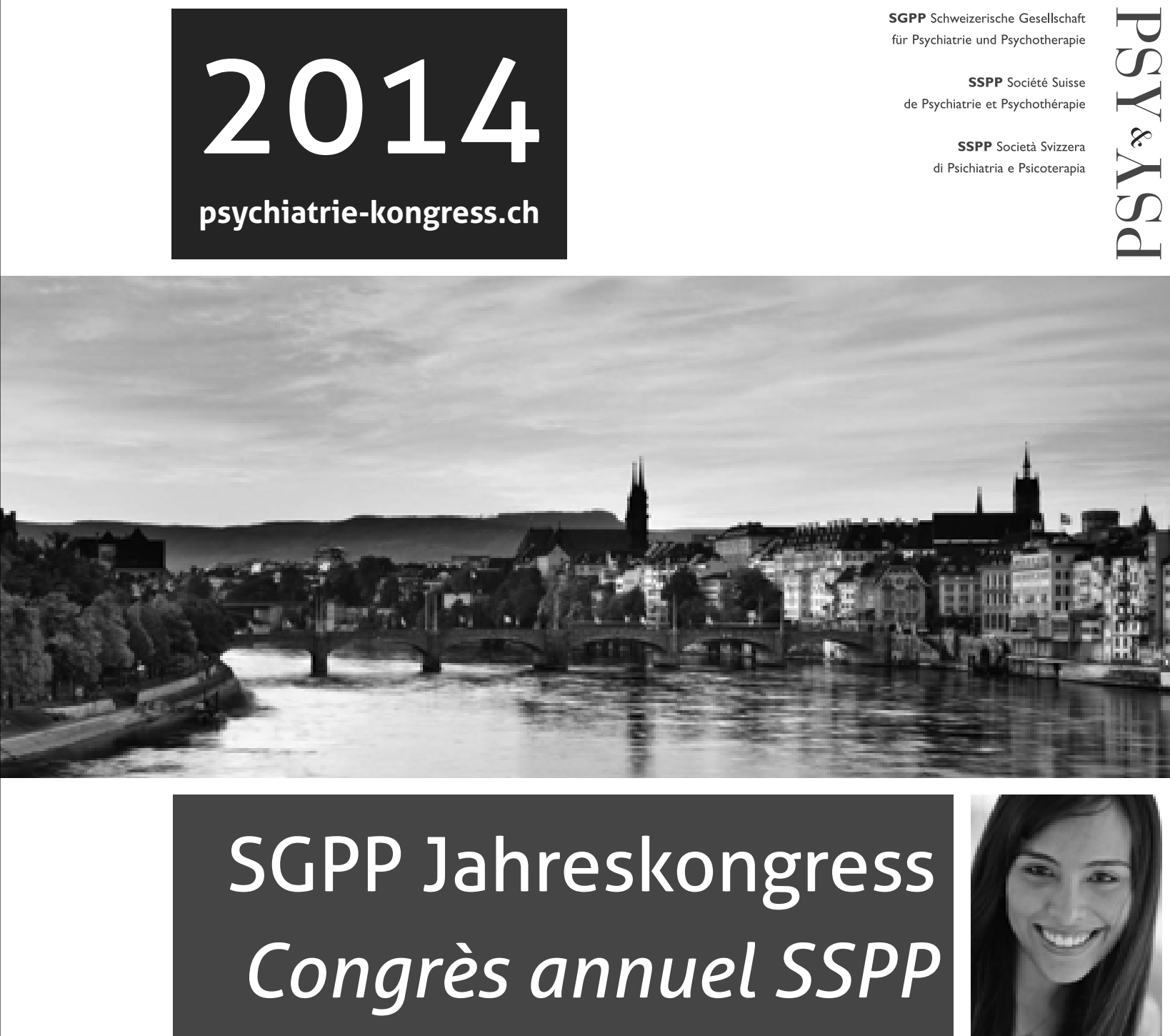

\section{Auf gleicher Augenhöhe \\ Sur pied d'égalité}

10.-12.09.2014

Congress Center Basel
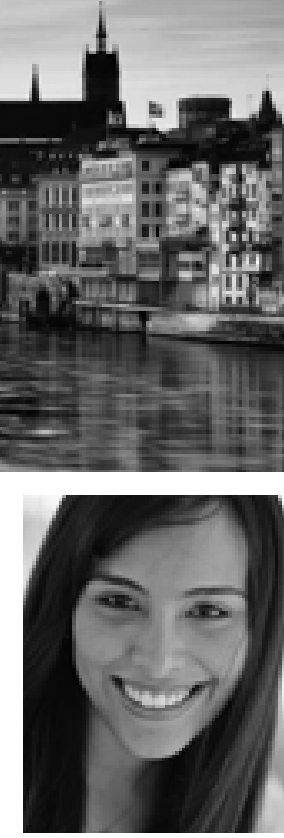


\section{Contents}

See the journal website for contents

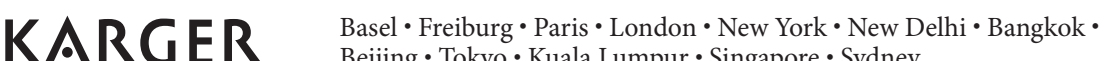
Beijing $\cdot$ Tokyo $\cdot$ Kuala Lumpur $\cdot$ Singapore $\cdot$ Sydney 

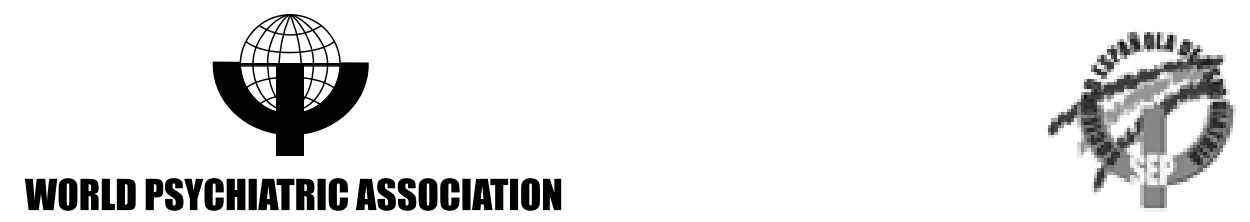

\section{AIE}

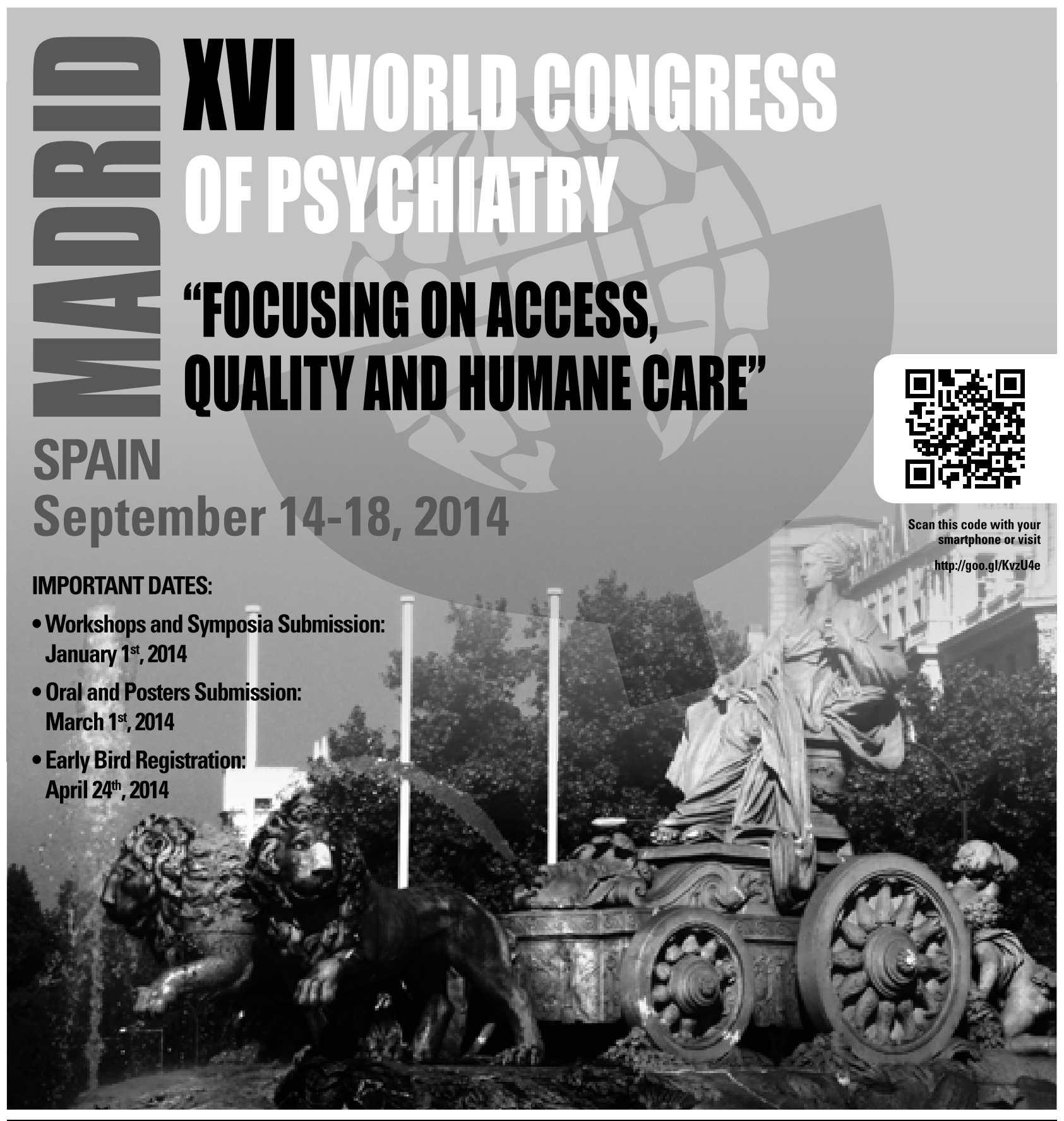

WwW.wpamadrid2014.com 


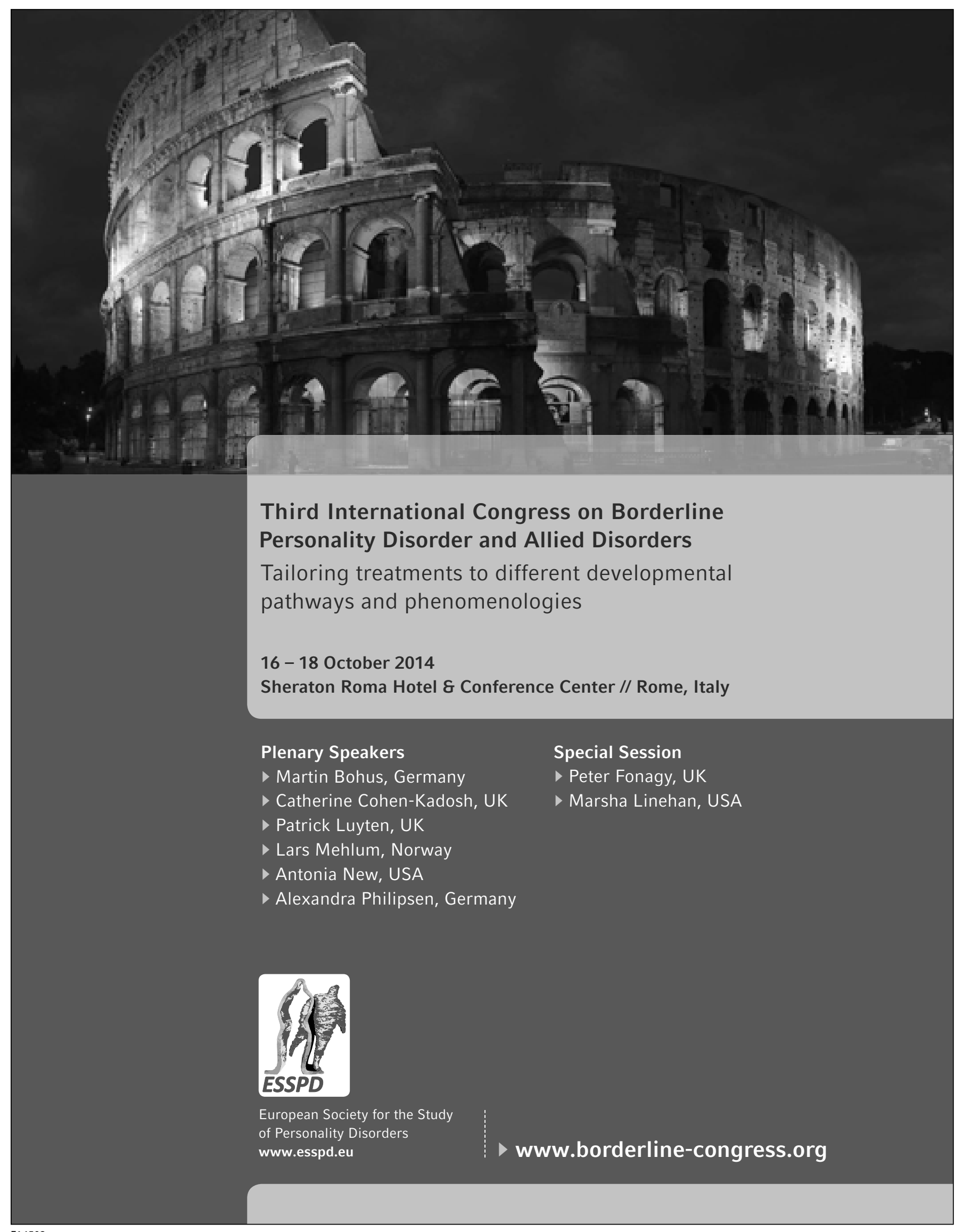


German Association

for Psychiatry, Psychotherapy

and Psychosomatics

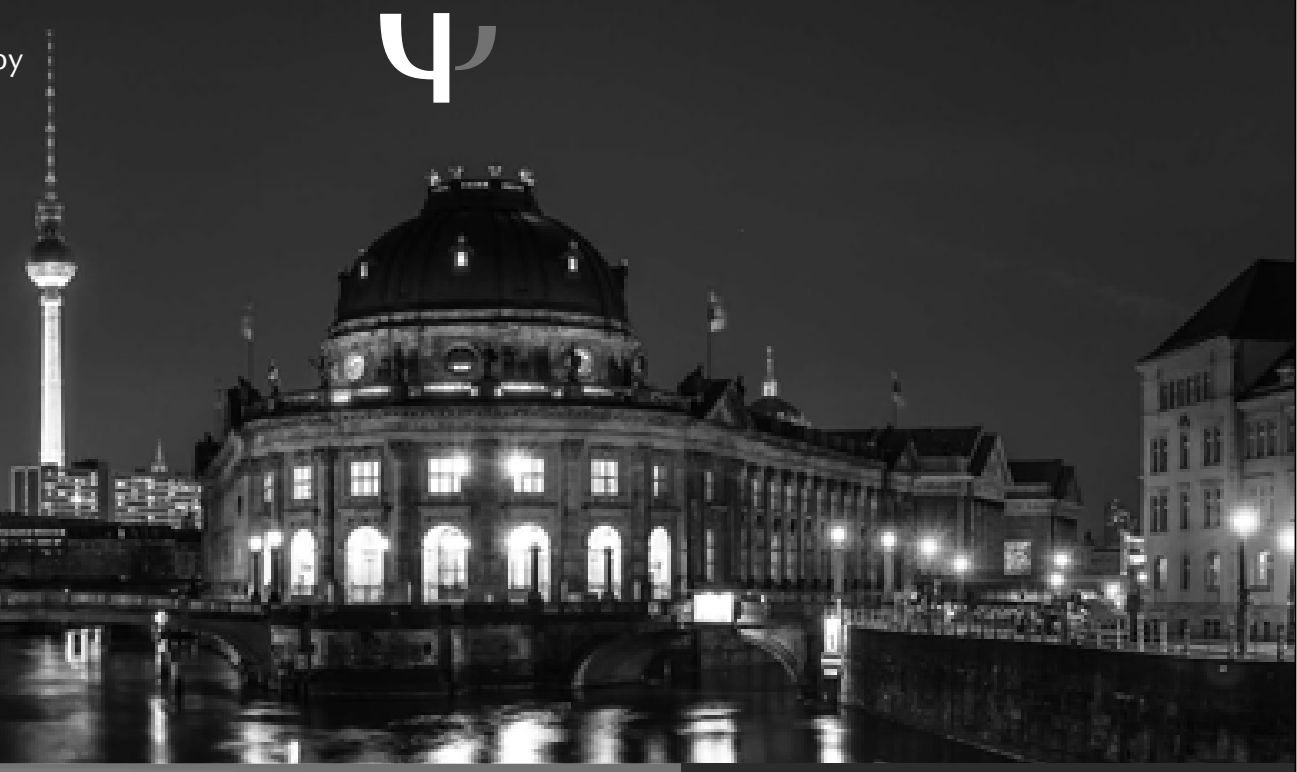

WWW.DGPPN.DE/ CONGRESS

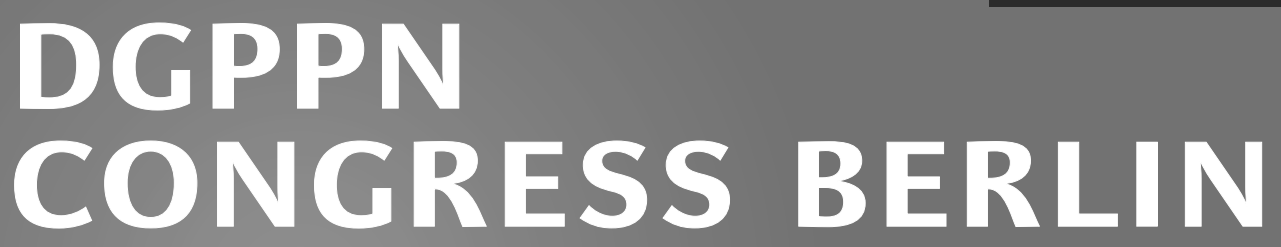

\section{6-29 November 2014 | CityCube Berlin | Germany}

The challenges of demographic change - Mental illnesses today and tomorrow

Ihe psyche in borderline situations

I Psychotherapy in older age

I Drug safety in an ageing society

Up to 30 CME credits

I English-language programme with renowned international experts

I Dementias and multimorbidity

I Mind-reading, neuroimaging and imaging

I Greatly extended educational programme in English

I Evaluation of criminal liability and violence risk assessment by neuroimaging?

I Treatment ethics and physician-assisted suicide

I Young Psychiatrists programme

DGPPN
Reinhardtstraße 27 B | 10117 Berlin | Germany PHONE +49 (0) $30-24047720$ programm@dgppn.de

Congress and Exhibition Office CPO HANSER

CPO HANSER SERVICE CmbH I Office Berlin Paulsborner Straße 44 | 14193 Berlin | Germany dgppn14@cpo-hanser.de 


\section{Kurt Schneider Scientific Award 2014}

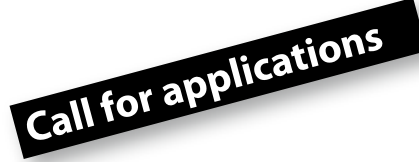

The Kurt Schneider Scientific Award for exceptional scientific achievements, endowed with $€ 10.000$, will be granted for the 13th time to one of the international applicants at the 19th Weißenauer Schizophrenia Symposium in the Cologne Maternushaus (12.-13.12.2014).

The prize was founded to encourage and honor psychiatric research, especially in schizophrenia including basic research (clinical psychopathology, biochemistry, neurophysiology, psycho-pharmacology, genetics, and epidemiology), diagnostics, prevention, therapy and rehabilitation.

Deadline for submission: September 15, 2014

www.uk-koeln.de/weissenauer
Your application must include:

- an accompanying letter setting out reasons supporting the application

- up to three thematically related original publications in German or English (not older than five years or manuscripts recently accepted for publication)

- an up-to-date curriculum vitae documenting professional experience and expertise

- a list of publications

- 8 hardcopies of the entire application documents for the members of the Scientific Award Selection Committee

Please send your application to: Professor Dr. med. Joachim Klosterkötter Department of Psychiatry and Psychotherapy University of Cologne 50924 Cologne, Germany Fon: +49 (0)221-478-4010 Fax: +49 (0)221-478-5593

\section{A new vision to understanding medicine} Handbook of Clinical Gender Medicine

\section{Editors: Karin Schenck-Gustafsson (Stockholm), Paula R. DeCola, Donald W. Pfaff (New York, N.Y.), David S.Pisetsky (Durham N.C.)}

In well-referenced chapters, experts cogently and concisely explain how the incorporation of gender issues into research can affect the medical understanding and treatment of heart disease, osteoporosis, arthritis, pain as well as malaria among other conditions.

This intriguing and unique medical textbook provides readers with a valuable new perspective on how to incorporate gender issues into the different branches of medicine.

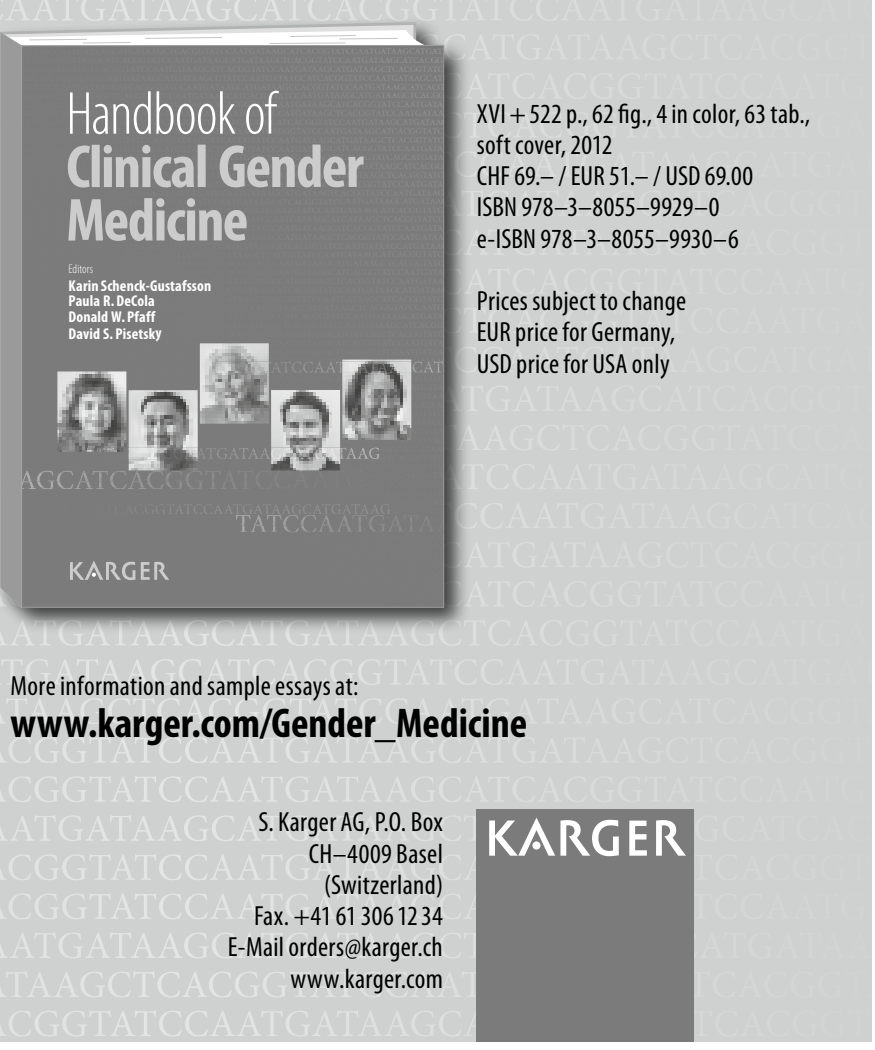




\section{Practical methods for implementing light and wake therapy to fight depression}

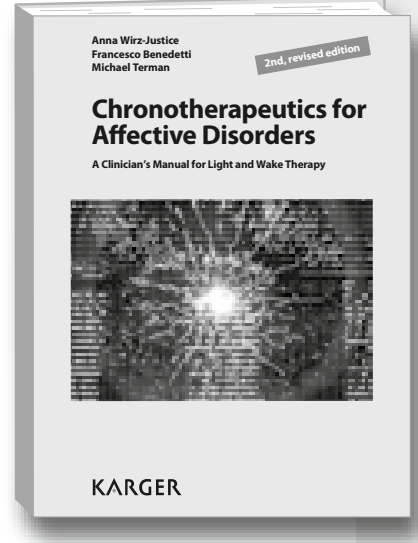

\section{Anna Wirz-Justice, Franceso Benedetti, Michael Terman \\ Chronotherapeutics for Affective Disorders}

\author{
A Clinician's Manual for Light and Wake Therapy
}

\section{2nd, revised edition}

Wirz-Justice, A. (Basel); Benedetti, F. (Milano); Terman, M. (New York, N.Y.)

Chronotherapeutics for Affective Disorders A Clinician's Manual for Light and Wake Therapy 2nd, revised edition

XII + 124 p., 33 fig., 21 in color, 10 tab., 2013 CHF 41.- / EUR 34.- / USD 48.00 (soft cover) CHF 49.- / EUR 41.- / USD 58.00 (online) Online version for institutional purchase Prices subject to change

EUR price for Germany, USD price for USA and Latin America only

ISBN 978-3-318-02090-8 (soft cover) e-ISBN 978-3-318-02091-5

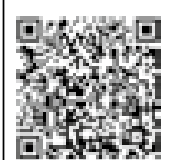

Dear Librarian

I have reviewed this publication and would like to recommend it for our library. Recommended by:

Department:
'Light therapy' is established worldwide as the treatment of choice for seasonal affective disorder. It is also successfuly used in nonseasonal depression, as well as for many other psychiatric and neurologic illnesses, and in sleep medicine. 'Wake therapy' is the fastest antidepressant known. Imaging studies show that both methods share neurobiological substrates with antidepressants, but act much faster. 'Chronotherapeutics' - the combination of light and wake therapy - achieves rapid results and, by reducing residual symptoms, also minimises relapse.

Written by three prominent clinical and research experts in biological rhythms, this manual aims to broaden knowledge and practical application of these non-pharmacologic interventions for bipolar and unipolar disorders. Clinical understanding is deepened by an explanation of the circadian timing system and sleep regulatory mechanisms which underlie the novel treatment strategy. The step-by-step guide and description of the interventions in centers throughout the world provides clear hands-on instructions, supported by a solid body of clinical research.

The first edition of 'Chronotherapeutics for Affective Disorders' has kindled a network of psychiatrists and psychologists who are actively introducing these treatments for their inpatients and outpatients. This manual is also essential reading for primary care physicians, sleep medicine specialists and health care administrators.

\section{Contents}

- Introduction

- Individual Chronotherapeutic Elements: Light, Wake Therapy and Sleep Phase Advance

- Integrative Chronotherapeutics: Combinations of Light, Wake Therapy and Sleep Phase Advance

- Inpatient Procedures

- Practical Details for Wake Therapy

- Practical Details for Light Therapy

- Outpatient Treatment Strategies

- Range of Chronotherapeutic Indications

- Light Therapy for Children and Adolescents

- Light and Wake Therapy for Older Patients

- The Visually Impaired: More Sleep Disturbances, More Depression

- Endogenous and Exogenous Melatonin

- Drugs That Affect Rhythms (Chronobiotics)

- Social Rhythm Therapy

- Chronobiology in Everyday Life

- References

- Subject Index

- Appendix

\section{The easiest way to order: www.karger.com/chronotherapeutics}




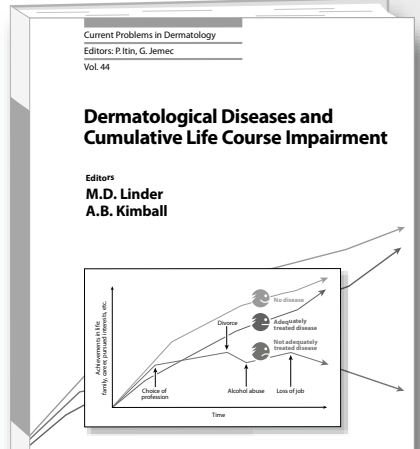

KARGER

\title{
Dermatological Diseases and Cumulative Life Course Impairment
}

\author{
Editors \\ Dennis M. Linder \\ Alexa B. Kimball
}

Dermatological Diseases and

Cumulative Life Course Impairment

Editors: Kimball, A.B. (Boston, Mass).

Linder, D.M. (Padua/Graz)

VIII + 162 p., 18 fig., 4 in color, 13 tab., 2013

CHF 197.- / EUR 164.- / USD 232.00 (hard cover)

CHF 236.- / EUR 197.- / USD 278.00 (online)

Online version for institutional purchase

Prices subject to change

EUR price for Germany, USD price for USA only ISBN 978-3-318-02403-6 (hard cover)

e-ISBN 978-3-318-02404-3

Current Problems in Dermatology, Vol. 44 Series Editors: Itin, P. (Basel);

Jemec, G.B.E. (Roskilde)

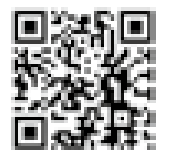

Dear Librarian

I have reviewed this publication and

would like to recommend it for our library.

Recommended by:

Department:

Date:

\section{Signature:}

Orders may be placed with any bookshop, subscription agency, directly with the publisher or through a Karger distributor.
This publication presents currently available evidence about the extent to which dermatological diseases may, through their own nature as well as a multitude of comorbidities and their important interactions with social life, impair the life course of patients.

Divided into four parts, the book starts with a brilliant introduction that highlights the importance of a life course approach in medicine from a medical as well as from a psychosocial point of view. The second part provides a basic presentation of the theoretical aspects of life course research and, more specifically, to the concepts of allostatic load and cumulative life course impairment $(\mathrm{CLCl})$. The third part examines concepts related to $\mathrm{CLCl}$, such as the 'quality of life in dermatology' or the 'major life changing decisions' influenced by dermatological diseases. The book concludes with an in-depth investigation of specific diseases where the concept of CLCl strikes as particularly relevant.

The new and innovative evidence presented in this publication makes it essential reading to anyone who has to take social implications of skin diseases into account in their decision making: dermatologists, allergologists, pediatricians and general practitioners as well as researchers in medical sociology or opinion leaders in public health.
Contents

Foreword: Giele, J.Z.

Introduction

Life Span and Life Course Approaches to Dermatological Disease: Ryff, C.D.

\section{Life Course, Life Course Modeling and}

\section{Life Course Damage}

Two Key Concepts in the Life Course Approach in Medicine:

Allostatic Load and Cumulative Life Course Impairment: Offidani, E.; Tomba, E.; Linder, M.D.

Mathematical Modeling in Life Course Research: Barban, N.; Linder, M.D.

Cumulative Life Course Impairment and Its Assessment Life Course Impairment and Quality of Life Over Time: Sampogna, F.

Concept of Major Life-Changing Decisions in Life Course Research: Bhatti, Z.U.; Salek, S.; Finlay, A.Y.

Setting Up a Life Course Questionnaire: Sampogna, F.

Cumulative Life Course Impairment: Identifying Patients at Risk: Augustin, $\mathbf{M}$.

\section{Cumulative Life Course Impairment in}

Dermatological Patients

Cumulative Life Course Impairment: Evidence for Psoriasis: Mattei, P.L.; Corey, K.C.; Kimball, A.B.

Cumulative Life Course Impairment by Epidermolysis Bullosa: Fine, J.-D.

Cumulative Life Course Impairment in Vitiligo: Krüger, C.; Schallreuter, K.U.

Cumulative Life Course Impairment in Melanoma and

Nonmelanoma Skin Cancer: Piaserico, S.

Cumulative Life Course Impairment in Chronic Wounds:

Augustin, M.

Cumulative Life Course Impairment in Dermatological Diseases Other Than Psoriasis: An Overview: Ibler, K.S Jemec, G.B.E.

Cumulative Life Course Impairment Across Cultures and

Medical Systems: Lima, X.T.

Patients' Narratives: Foulkes, A.C.; Warren, R.B.

Author Index/Subject Index 


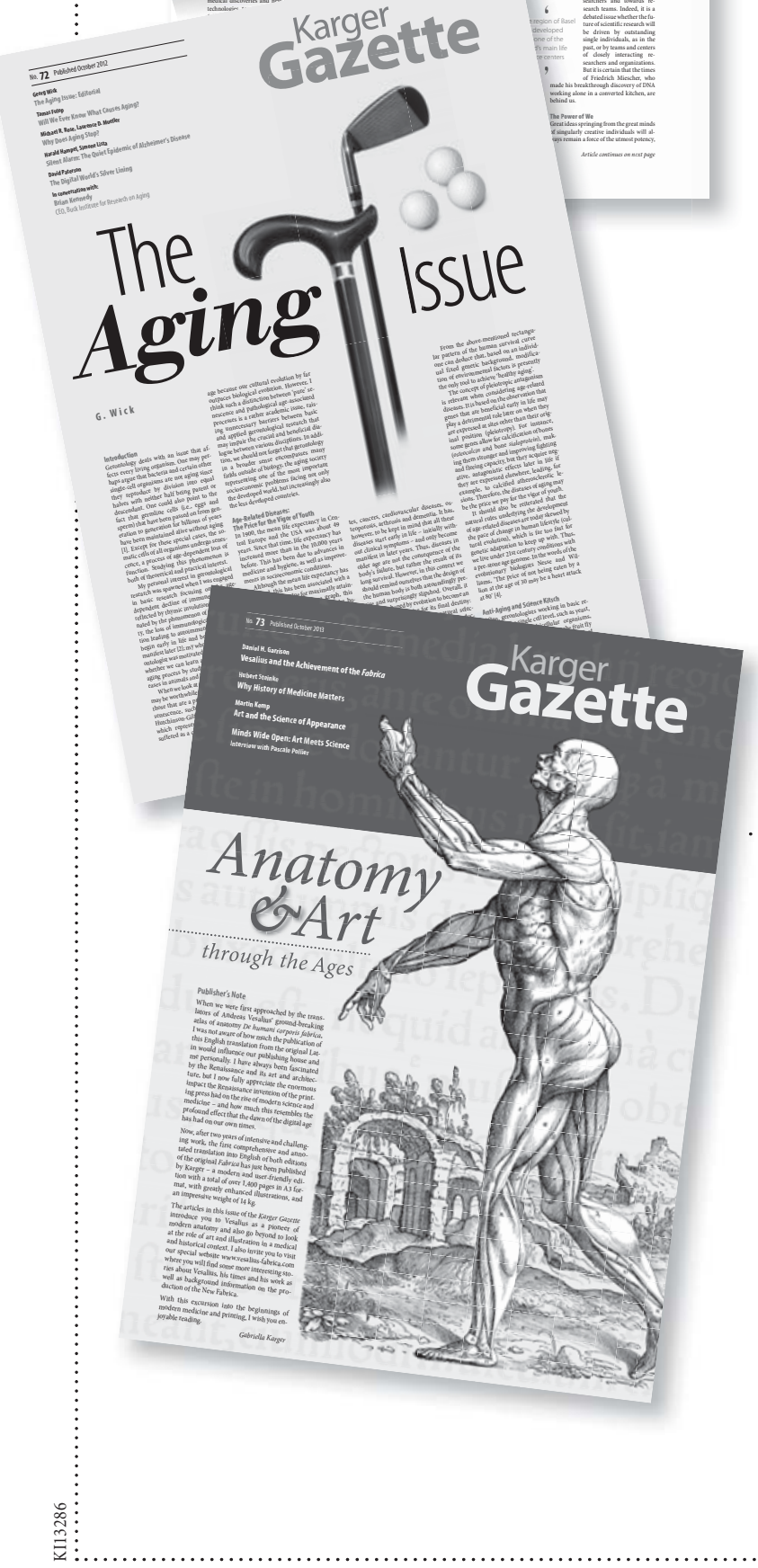

\section{Gazerte}

Stimulating reading in and around the world of medicine

The biomedical themes of the Karger Gazette are topical, urgent, exciting. Its articles, written by experts from all over the world, provide a wide audience with the basic issues, new findings and controversies in a lively and readable style. Alongside invited contributions, each number carries attractively presented support material, such as informative graphics, historical summaries, interviews, or portraits of individuals and institutions. The Karger Gazette is published in newspaper format and appears once a year.

And what's more - it's free!

To see behind the cover, please write or e-mail us, and we'll start your subscription with the latest issue.

www.karger.com/gazette

Current issue:

\section{Anatomy and Art through the Ages}

with articles on

- Andreas Vesalius, his times and his ground-breaking atlas 'De humani corporis fabrica'

- Why history of medicine matters

- Art and the science of appearance

- Medical art and illustration

\section{KARGER $\begin{gathered}\text { s. Karger AG } \\ \text { Karger Gazette }\end{gathered}$}

Allschwilerstrasse 10

CH-4009 Basel (Switzerland)

E-Mail gazette@karger.com

www.karger.com 


\section{Psychopathology}

Review

141 Creativity and Psychopathology: A Systematic Review

Thys, E. (Leuven/Brussels); Sabbe, B. (Antwerp/Duffel); De Hert, M. (Leuven)

Original Papers

148 Susceptibility to Distraction by Social Cues in Borderline Personality Disorder Krause-Utz, A. (Mannheim); Elzinga, B.M.; Oei, N.Y.L.; Spinhoven, P. (Leiden); Bohus, M.; Schmahl, C. (Mannheim)

158 Should Definitions for Mental Disorders Include Explicit Theoretical Elements? Adan-Manes, J.; Ramos-Gorostiza, P. (Madrid)

167 Creativity, Alcohol and Drug Abuse: The Pop Icon Jim Morrison Holm-Hadulla, R.M. (Heidelberg/Santiago); Bertolino, A. (Heidelberg)

174 Subjective Experience of Thought Overactivation in Mood Disorders: Beyond Racing and Crowded Thoughts

Keizer, I.; Piguet, C.; Favre, S.; Aubry, J.-M.; Dayer, A. (Geneva); Gervasoni, N. (Nyon); Gex-Fabry, M. (Geneva); Bertschy, G. (Strasbourg)

185 Assessment of Personality Functioning: Validity of the Operationalized Psychodynamic Diagnosis Axis IV (Structure)

Doering, S. (Vienna); Burgmer, M.; Heuft, G.; Menke, D. (Münster); Bäumer, B. (Senden); Lübking, M. (Münster); Feldmann, M. (Rhede); Schneider, G. (Münster)

194 Self-Reported Psychotic-Like Experiences Are a Poor Estimate of Clinician-Rated Attenuated and Frank Delusions and Hallucinations

Schultze-Lutter, F. (Bern/Cologne); Renner, F. (Maastricht); Paruch, J.; Julkowski, D.; Klosterkötter, J.; Ruhrmann, S. (Cologne)

Short Report

202 Epidemiology, Course and Outcome of Acute Polymorphic Psychotic Disorder: Implications for ICD-11

Castagnini, A.; Foldager, L. (Aarhus) 